\title{
Actinobacillus actinomycetemcomitans
}

\author{
BRIAN HENDERSON, MICHAEL WILSON*, LINDSAY SHARP and JOHN M. WARD† \\ Cellular Microbiology Research Group and*Microbiology Department, Eastman Dental Institute, University \\ College London and †Department of Biochemistry and Molecular Biology, University College London, London
}

\section{Introduction}

The recent report of the American Surgeon General on oral health in the USA [1] has shone the spotlight on what is termed 'the silent epidemic of oral diseases which disproportionately burdens minorities and the poor'. This silent epidemic is caused primarily by certain members of the oral microbiota, which are responsible for two of our most prevalent diseases dental caries and periodontitis. It is surprising to realise that in the USA, the richest country on our planet, dental caries is the single most common chronic childhood disease, being five times more common than asthma [1]. Severe periodontal disease in the USA affects $14 \%$ of adults aged $45-54$ and $23 \%$ of those aged 65-74 years. These prevalence figures are alarming, particularly as in recent years evidence has begun to accrue to suggest that dental 'infection' may be a predisposing factor in systemic conditions such as coronary heart disease (CHD), diabetes and low birth weight $[2,3]$.

The periodontal diseases affect the gums (gingivae), the periodontal ligament and the alveolar bone. Inflammation of the gums affects all of us at some time in our lives, and is known as gingivitis. If, in addition to the inflammation in the gums, the periodontal ligament and alveolar bone that support our teeth are also affected, and begin to be destroyed, the disease is known as periodontitis. This term encompasses a number of clinically defined conditions [4]. The periodontal diseases are not classical exogenous infectious diseases, and there is good evidence that they are caused by certain members of the normal oral microbiota, principally gram-negative anaerobes [5].

Received 12 June 2002; accepted 24 June 2002.

Corresponding author: Professor B. Henderson (e-mail b.henderson@eastman.ucl.ac.uk).
The periodontal disease with the clearest association with an oral bacterium is a curious condition known as localised aggressive periodontitis (LAP), previously known as localised juvenile periodontitis [4]. This disease affects only certain teeth (incisors and premolars) and causes rapid loss of the alveolar bone of the jaw leading to tooth loss [6]. The major causative agent of LAP is Actinobacillus actinomycetemcomitans [7], which is the subject of this review. This organism has also been known to cause infective endocarditis [8].

In a US national survey the mean prevalence of LAP among adolescents of all racial origins was $0.53 \%$, which makes it a reasonably common disease. However, adolescents of African-American descent were found to have a 15-fold higher incidence of disease than Caucasian Americans [9]. In Brazil, one study found that $3.7 \%$ of 15-16-year-old adolescents had LAP [10]. In Nigeria, a prevalence of $0.8 \%$ was found $[11,12]$. Kilian and co-workers have established a relationship between LAP in individuals of African origin and a particular clone of A. actinomycetemcomitans (JP2) which has a 530-bp deletion from the promoter region of the leukotoxin gene operon - one of this organism's many putative virulence factors. Furthermore, these workers found that in about half of the families from which the JP2 clone was isolated more than one family member had LAP [13]. This virulent clone is absent from Northern European Caucasians [14] who are colonised by a range of clonally distinct organisms. Thus, in most of the world, A. actinomycetemcomitans is presumably an opportunist pathogen. However, in adolescents of African origin A. actinomycetemcomitans (or at least a particular clone) appears to be an exogenous pathogen [13].

The possible role of genetic factors in LAP has been under investigation since the 1980s [15]. An early discovery was a defect in neutrophil chemotaxis to the bacterial chemoattractant formyl-methionine-leucinephenylalanine (FMLP) [16]. Genetic analysis of 30 
patients with LAP has recently shown that 29 had point mutations in the gene encoding the formyl peptide receptor [17] and these mutations have been found to be associated with almost complete loss of receptor signalling in response to FMLP [18]. Why this apparent major defect in neutrophils does not result in susceptibility to other bacteria, and only seems to increase susceptibility to A. actinomycetemcomitans, is unexplained.

This short review will introduce the reader to $A$. actinomycetemcomitans, an oral commensal which is also an opportunist pathogen with a distinct racial bias and a surprising range of potential virulence factors and virulence mechanisms. In addition, there is evidence that this bacterium may play some role in systemic diseases such as coronary artery disease.

\section{Actinobacillus actinomycetemcomitans - the cell}

First described in 1912 and variously named over the intervening years, A. actinomycetemcomitans was recognised as a member of the normal human oral microbiota in the 1950s [19]. It is also found in the oral cavities of a number of primates and other mammals. The primary habitat has not been definitively identified but is most probably dental plaque in the gingival crevice [20], as it is not found in edentulous individuals $[21,22]$. This organism is a gram-negative, non-spore-forming, non-motile, facultatively anaerobic coccobacillus that grows best in an aerobic environment enriched with $\mathrm{CO}_{2} \quad 5-10 \%$. Growth is optimal at $37^{\circ} \mathrm{C}$, over the $\mathrm{pH}$ range $7-8.5$, and can be stimulated by a number of low molecular mass reagents including various steroid hormones [23]. The cells are straight or curved rods with rounded ends c. $1.0-1.5 \mu \mathrm{m}$ by $0.4-0.5 \mu \mathrm{m}$. Freshly isolated bacteria produce small crinkled adherent (rough) colonies (1-2 mm diameter) on agar with a star-shaped (Greek aktinos, ray) structure in the centre. Certain strains and fresh isolates of $A$. actinomycetemcomitans in medium have the ability to adhere tightly to themselves or to substrata such as glass, plastic and hydroxyapatite [24-28]. Adhesion has been thought to be due to the presence of large bundled fibres on the bacterial surface $[25,26]$. Analysis of the tight binding of $A$. actinomycetemcomitans has led to the discovery of a gene cluster, termed tad (tight adherence), containing seven novel genes [28-31]. Another gene, impA, has been proposed to contribute to this tight binding phenotype [32]. It is also established that A. actinomycetemcomitans can bind to extracellular matrix components such as collagen and fibronectin [33]. Serologically, six serotypes $(\mathrm{a}-\mathrm{f})$ of the O-polysaccharide component of lipopolysaccharide are recognised currently [34] and it is suggested that all have pathogenic potential [35].

\section{Virulence factors of Actinobacillus actinomycetemcomitans}

It must be emphasised that, although a large number of 'virulence factors' of A. actinomycetemcomitans have been identified, there have been no in-vivo studies with isogenic mutants to establish that any of these proteins are implicated in tissue pathology. The tissue pathology that this bacterium is responsible for includes inflammation of the gingivae (gums) and destruction of the periodontal ligament and alveolar bone, which link the teeth to the jawbone. The putative virulence factors of A. actinomycetemcomitans can be subdivided into those that: (i) modulate inflammation, (ii) induce tissue destruction and (iii) inhibit tissue repair. As expected, many of the individual putative virulence factors have overlapping actions.

\section{Immunomodulatory 'virulence' factors}

A. actinomycetemcomitans appears to employ multiple gene products to inactivate or evade immune defences. The most actively studied gene product of this organism is a leukotoxin and a member of the RTX (repeats in toxin) family [36,37] whose cellular receptor is the $\beta_{2}$-integrin, LFA-1 [38], thus accounting for its selective effect on leucocytes (although only those from primates). The leukotoxin operon consists, in transcription order, of four genes $\operatorname{ltx} C, A, B$ and $D$. The LtxA protein is the active toxin and this has to be acylated, by LtxC and an acyl carrier protein, to be biologically active. The other two proteins are responsible for transport and secretion of LtxA [39]. The RTX leukotoxins are secreted, and the only exception to this is the LtxA toxin of $A$. actinomycetemcomitans which had been thought to be entirely cell associated; either bound to cell surface-associated nucleic acids [40] or within membranous vesicles which bud from the bacterium's surface [41,42]. This means that the bacterium itself is toxic to target cells [43]. More detailed analysis has revealed that adherent (or rough) colonies of $A$. actinomycetemcomitans do not secrete leukotoxin but non-adherent (smooth colonies) do [44]. Bacteria with mutations in the tad operon were found to secrete the leukotoxin, suggesting that binding of this toxin to $A$. actinomycetemcomitans is in some manner dependent on proteins expressed by tad genes [44]. The response of target cells to the A. actinomycetemcomitans leukotoxin is to undergo apoptosis [45] by a mechanism involving mitochondrial perturbation [46].

Various other undefined and ill-defined proteins have been claimed to be either directly immunomodulatory or immune-modulating as a result of the ability to inhibit cell cycle progression. Indeed, injection of $A$. actinomycetemcomitans into mice has been claimed to induce immunosuppression [47] and sonicates of this organism suppressed the $\mathrm{IgG}$ response to sheep red blood cells in mice [48]. A $14-\mathrm{kDa}$ immunosuppressive 
protein able to inhibit lymphokine production was isolated from $A$. actinomycetemcomitans [49] and the $\mathrm{N}$-terminal sequence identified it as thioredoxin, an intracellular protein which is a redox controlling/cell stress protein, known to have cytokine-like properties [50]. However, when the thioredoxin of A. actinomycetemcomitans was cloned and expressed, the recombinant protein, which was enzymically active, failed to inhibit lymphokine or cytokine synthesis [51]. This immunosuppressive protein presumably co-purifies with thioredoxin and still remains to be identified.

Superantigens are generally bacterial proteins that activate $\mathrm{T}$ cells bearing specific $\mathrm{V} \beta$ T-cell receptors. One consequence of such activation is that the $\mathrm{T}$ cells apoptose and thus superantigens can be considered as immunosuppressants. A. actinomycetemcomitans has been reported to produce an as yet unidentified superantigen which rapidly causes T-cell apoptosis $[52,53]$.

A. actinomycetemcomitans has been reported to produce a number of, as yet unidentified, proteins with cell cycle-inhibitory activity causing arrest in the $G_{2}$ phase of the cell cycle. These proteins range in molecular mass from the $8-\mathrm{kDa}$ protein termed gapstatin $[54,55]$ to $60 \mathrm{kDa}$ [56] and all the way up to $80 \mathrm{kDa}$ [57]. A proportion of the sera from patients with LAP contained antibodies that were able to inhibit the cell cycle-inhibiting activity of gapstatin [54]. One cell cycle-modulatory protein with immunosuppressive function that has recently been identified as being produced by $A$. actinomycetemcomitans is cytolethal distending toxin (CDT) [58,59]. This toxin is the product of a three gene operon ( $c d t A, c d t B, c d t C$ ) which is found in a range of bacteria including Escherichia coli, Shigella spp., Campylobacter spp., Helicobacter spp. and Haemophilus ducreyi [58]. The mechanism of action of this toxin is believed to be due to the nuclease activity of CdtB [60]. In some, as yet unexplained manner, $\mathrm{CdtA}$ and $\mathrm{CdtC}$ are believed to facilitate the entry of CdtB into host cells. The CdtB is believed to enter into the nucleus and degrade chromosomal DNA, thus inducing cell cycle arrest via specific checkpoint kinases [59]. There is significant sequence variation in the $c d t$ genes between bacteria, and phylogenetic analysis reveals that the $c d t$ genes of $A$. actinomycetemcomitans [61, 62] most closely resemble those of $H$. ducreyi, the bacterium responsible for the sexually transmissible disease, chancroid [59]. The CDTs of all bacteria, other than A. actinomycetemcomitans, require all three CDT proteins for cell cycle inhibition. However, Shenker and colleagues have reported that purified or recombinant $A$. actinomycetemcomitans $\mathrm{CdtB}$ is sufficient to block human lymphocyte cell cycle progression [63-65]. We have found that the combination of CdtB and $\mathrm{CdtC}$ from $A$. actinomycetemcomitans will induce cell cycle arrest of HEp-2 cells [66]. The combination of all three toxin proteins will also stimulate human monocytes to produce certain cytokines. Most unusually, the cytokine network produced by these toxin proteins includes the early response cytokine, IL- $1 \beta$, but not its usual partner cytokine, tumour necrosis factor- $\alpha$ (TNF- $\alpha)$ [66]. We have also found that CdtC binds to cell membranes and acts as a receptor for CdtB allowing the latter to enter into cells [67]. Thus, at the moment it appears that the CDT proteins of $A$. actinomycetemcomitans have some differences in their interaction with host cells compared with homologous proteins from other bacteria. The possible role of CDT in the virulence of $A$. actinomycetemcomitans has yet to be determined and the finding that inactivation of the CDT operon in $H$. ducreyi had no effect on virulence in a human skin model [68] is suggestive.

Another potentially immunosuppressive virulence factor of A. actinomycetemcomitans is an Fc-binding protein [69]. This was identified as a heat-modifiable outer-membrane protein [70]. The gene encoding this protein was cloned and encodes a protein of $35 \mathrm{kDa}$, which was termed Omp34 [71]. The Omp34 protein has $54 \%$ identity with OmpA of $E$. coli, a protein implicated in the virulence of this organism [72]. $A$. actinomycetemcomitans produces a $65-\mathrm{kDa}$ macromolecule able to bind to the IL-10 receptor [73]. IL-10 is a major macrophage-de-activating cytokine and the biological activity of this molecule may either mimic or antagonise IL-10, thus modulating monocyte/macrophage function.

In addition to being able to inhibit lymphocyte and monocyte function, A. actinomycetemcomitans has been reported to produce a low molecular mass inhibitor of neutrophil chemotaxis to FMLP [74].

While many immunosuppressive factors have been described, there are fewer reports of immunostimulatory factors from $A$. actinomycetemcomitans. Direct culture of $A$. actinomycetemcomitans with human gingival epithelial cells induces the production of IL$1 \beta$, IL- 8 and ICAM- 1 but not IL-6 $[75,76]$. In contrast, human gingival fibroblasts cultured in the presence of A. actinomycetemcomitans expressed mRNA for IL-6 and IL- 8 but not IL- $\beta$ [76]. We know very little about the cytokine-inducing components of A. actinomycetemcomitans. The activity of lipopolysaccharide will be discussed in the next section. A 2-kDa peptide, which induced human gingival fibroblasts to synthesise IL-6 without also inducing IL- $1 \beta$ and TNF- $\alpha$, is secreted by A. actinomycetemcomitans [77] and may explain the results found with the intact organism [76]. A $37-\mathrm{kDa}$ secreted immunogenic glycoprotein has also been reported to stimulate murine macrophages to produce IL-1 $\beta$, IL-6 and TNF- $\alpha$ [78]. A. actinomycetemcomitans has also been reported to secrete mitogenic proteins [79], including a $13-\mathrm{kDa}$ B-cell mitogen [80].

Bacterial capsules normally play a major role in bacterial virulence because of their role in immune 
evasion. Little is known about the role of $A$. actinomycetemcomitans capsular polysaccharides in the interactions of this organism with the host. The finding that the various serotypes of $A$. actinomycetemcomitans contain the unusual sugar, 6-deoxy-Dtalose, and the identification of a unique gene encoding the protein involved in the synthesis of this sugar $[81,82]$ suggests that the capsule of this bacterium may have unusual properties.

\section{'Virulence' factors inducing tissue destruction}

LAP is a very aggressive disease resulting in rapid destruction of the periodontal ligament and alveolar bone. The promotion of bone resorption requires interactions between the bone-forming mesenchymal cell, the osteoblast, and the myeloid multinucleate bone-resorbing cell, the osteoclast [83]. The main signals transferred between these cells are cytokines particularly members of the TNF family, including TNF- $\alpha$ and the newly discovered cell surface cytokine, RANKL (receptor-activator of NF- $\kappa \mathrm{B}$ ligand), on the osteoblast. This cell-bound cytokine is the ligand of RANK on the osteoclast plasma membrane. Binding of RANKL to RANK on osteoclast precursor cells stimulates the production of mature osteoclasts. Osteoblasts also produce a soluble protein resembling RANK, called osteoprotegerin, which acts as a RANK antagonist or decoy receptor [84].

With all bacterial diseases involving inflammation and tissue destruction, LPS is always considered to be a key virulence factor. This needs to be re-examined with oral bacteria in light of reports that LPS from certain oral organisms is an antagonist of human toll-like receptor (TLR)4, one of the major cellular LPS receptors [85]. A. actinomycetemcomitans LPS is reported to stimulate bone resorption in vitro $[86,87]$ and in vivo [88]. However, the authors of this review have established that the LPS from A. actinomycetemcomitans is a significantly less active cytokine inducer than the proteins secreted by the bacterium [89]. Among these secreted proteins is a potent bonedegrading molecule that was identified as the cell stress protein, chaperonin 60 [90]. This molecular chaperone, which is normally intracellular, appears to be secreted by this bacterium $[90,91]$ and stimulates bone resorption by acting as an osteoclast 'growth factor' [92]. A serotype-specific capsular polysaccharide antigen of $A$. actinomycetemcomitans has been reported to stimulate osteoclast formation [93] and induce apoptosis of an osteoblast-like cell line [94]. A role for antigen-driven $\mathrm{T}$ cells in alveolar bone resorption induced by $A$. actinomycetemcomitans has been postulated. Gingival injection of the outermembrane protein (Omp34) [71] in rats after transfer of antigen-specific Th1 lymphocytes, but not Th2 cells, resulted in alveolar bone resorption. Such bone destruction was blocked by antagonism of CD80, the co-stimulatory signal for $\mathrm{T}$ cells [95]. $\mathrm{T}$ cells express the osteoclast-activating cytokine RANK described above. In studies with NOD/SCID mice, which can accept human tissues and cells without inducing graft rejection, it was found that mice repopulated with peripheral $\mathrm{T}$ cells from periodontitis patients undergo alveolar bone destruction when orally challenged with A. actinomycetemcomitans. Bone destruction was inhibited by administration of the decoy receptor, osteoprotegerin, demonstrating that the antigen-specific induction of RANK by human T cells was the probable cause of the bone resorption [96].

\section{Virulence mechanisms of $A$. actinomycetemcomitans}

\section{Adhesion}

Bacterial adhesion is required for colonisation and is a key virulence mechanism [97]. The tight auto-adhesion of A. actinomycetemcomitans has been described [24-28] and is due to the expression of long, bundled fibrils $[98,99]$ composed of a $6.5-\mathrm{kDa}$ subunit protein, Flp-1 (fimbrial low-mol. wt protein) [100], which has been reported to be glycosylated [101]. Transposon mutagenesis with a novel transposon, IS903 $\phi \mathrm{kan}$, identified a cluster of novel genes - tadABCDEFG where tad stands for 'tight adherence' - involved in bacterial adhesion [28-31]. IS903 $\phi$ kan insertion mutans of $f p-1$ also lack tight adhesion [30]. The most satisfactory explanation is that tadABCDEFG genes, which are arranged like an operon, are linked to the $f l p-1$ gene. Indeed, the $f p-1$ gene is found upstream of the tad operon in a low $\mathrm{G}+\mathrm{C}$ region (similar $\mathrm{G}+\mathrm{C}$ ratio to the tad operon) along with two other genes ( $r c p A$ and $r c p B$ ) expressed specifically in rough adherent bacteria but not in smooth mutants [102]. The relationship between the tad operon and $f p$-1 is that the former is a secretion system for the latter [31]. The TadA protein has significant homology to NTP hydrolase proteins involved in type II and type IV secretion systems and similar tad loci are found in the genomes of gram-negative, gram-positive bacteria and in Archaea [29]. The low $\mathrm{G}+\mathrm{C}$ content of the tad locus suggests that it may have been horizontally transferred [31]. The role of the $\operatorname{tadA}$ locus in the pathogenesis of LAP is not known but a tadD isogenic mutant of Pasteurella multocida, a bacterium showing many similarities to $A$. actinomycetemcomitans, was less virulent in a mouse model of infection [103].

\section{Invasion}

It is established that many bacteria can invade host cells, at least in vitro, and invasiveness is a prerequisite for the pathology of certain bacterial pathogens [97]. Bacterial invasion is a complex process dependent on both the bacterium and the host cell [104]. Most bacteria utilise the actin microfilaments for uptake and intracellular movement but there is increasing evidence that microtubules are also important [104]. Studies of 
invasion by $A$. actinomycetemcomitans have been limited in respect of the bacterial strains and human cells used but have revealed that $25 \%$ of $A$. actinomycetemcomitans isolates are invasive $[105,106]$. The identity of the host cell surface receptor that binds to $A$. actinomycetemcomitans and initiates invasion is not firmly established. It has been suggested that the transferrin and integrin receptors are involved [107]. Alternatively, uptake, at least into vascular endothelial cells, has been proposed to utilise the platelet-activating factor (PAF) receptor which binds phosphorylcholine [108]. Binding and invasion of Haemophilus influenzae also utilises the PAF receptor [109]. It is not known if the Flp-1 protein is involved in adhesion to host cells. The uptake of $A$. actinomycetemcomitans into the HEp-2 cell line is blocked by monodansylcadaverine, implicating a receptor-mediated endocytotic uptake pathway and is also blocked by cytochalasin $\mathrm{D}$, implying a role for the actin cytoskeleton in uptake [110]. This is similar to reports with many other bacteria [97, 104]. However, unusual aspects of the behaviour of A. actinomycetemcomitans are its rapid exit from cells after invasion, its ability to move from one cell to another and its capacity to divide rapidly within host cells [111]. The process of intracellular movement and the cell spreading could be inhibited by agents that interfered with microtubule dynamics, suggesting that this bacterium interacts closely with the microtubules of the host cell [112].

The relevance of these in-vitro studies has been brought into focus by the report that buccal epithelial cells of 23 of 24 individuals harboured oral bacteria including $A$. actinomycetemcomitans [113]. This shows that invasion is not an artefact of the tissue culture process but raises the very important question of the role of bacterial invasion in health and disease. Is invasion an evasion process or does it represent a closer relationship between the host and its commensal bacteria than has hitherto been believed?

\section{Global control of virulence}

Our understanding of the mechanisms involved in the global regulation of virulence genes is becoming clearer and quorum sensing is now identified as a key mechanism for such control [97]. It is now established that $A$. actinomycetemcomitans expresses a homologue of the LuxS protein of Vibrio harveyi and produces autoinducer II (AI-2). This AI-2 induced $A$. actinomycetemcomitans to produce both leukotoxin expression and a periplasmic iron transport protein [114]. Of interest is the fact that this AI-2 protein can interact with other bacteria and induce specific gene transcription [114].

\section{Conclusions}

A. actinomycetemcomitans is a bacterium with an array of diverse potential virulence characteristics, including multiple immune evasion mechanisms and novel mechanisms for binding to host matrices and invading host cells, any one of which may play a crucial role in the local tissue pathology of LAP. Our understanding of this organism still lags behind that of enteric pathogens, largely because methods for genetic manipulation have only just become available and the genome sequence, while almost complete, still awaits annotation. With the availability of such methodology and genome information we should begin to see rapid advances in understanding how $A$. actinomycetemcomitans produces such profound, but local, pathology and shed light on its ability to induce systemic pathology such as the recent report of glomerulonephritis caused by this bacterium [115].

\section{References}

1. Oral health in America: a report of the Surgeon General. Washington, DC, US Public Health Service. 2000.

2. Beck JD, Pankow J, Tyroler HA, Offenbacher S. Dental infections and atherosclerosis. Am Heart J 1999; 138: S528S533.

3. Lopez NJ, Smith PC, Gutierrez J. Higher risk of preterm birth and low birth weight in women with periodontal disease. $J$ Dent Res 2002; 81: 58-63.

4. Armitage GC. Development of a classification system for periodontal diseases and conditions. Ann Periodontol 1999; 4: $1-6$

5. Kuramitsu HK, Ellen RP. Oral bacterial ecology: the molecular basis. Norfolk, Wymondham Scientific Press. 2000.

6. Tonetti MS, Mombelli A. Early-onset periodontitis. Ann Periodontol 1999; 4: 39-53.

7. Slots J, Ting M. Actinobacillus actinomycetemcomitans and Porphyromonas gingivalis in human periodontal disease: occurrence and treatment. Periodontology 2000 1999; 20: $82-121$.

8. van Winkelhoff AJ, Slots J. Actinobacillus actinomycetemcomitans and Porphyromonas gingivalis in nonoral infections. Periodontology 2000 1999; 20: 122-135.

9. Loe H, Brown LJ. Early onset periodontitis in the United States of America. J Periodontol 1991; 62: 608-616.

10. Gjermo P, Bellini HT, Pereira Santos V, Martins JG, Ferracyoli JR. Prevalence of bone loss in a group of Brazilian teenagers assessed on bite-wing radiographs. J Clin Periodontol 1984; 11: $104-113$.

11. Macgregor ID. Radiographic survey of periodontal disease in 264 adolescent schoolboys in Lagos Nigeria. Community Dent Oral Epidemiol 1980; 8: 56-60.

12. Harley AF, Floyd PD. Prevalence of juvenile periodontitis in schoolchildren in Lagos Nigeria. Community Dent Oral Epidemiol 1988; 16: 299-301.

13. Haubek D, Dirienzo JM, Tinoco EMB et al. Racial tropism of a highly toxic clone of Actinobacillus actinomycetemcomitans associated with juvenile periodontitis. J Clin Microbiol 1997; 35: 3037-3042.

14. Haubek D, Poulsen K, Asikainen S, Kilian M. Evidence for absence in northern Europe of especially virulent clonal types of Actinobacillus actinomycetemcomitans. J Clin Microbiol 1995; 33: 395-401.

15. Dennison DK, Van Dyke TE. The acute inflammatory response and the role of phagocytic cells in periodontal health and disease. Periodontology 2000 1997; 14: 54-78.

16. McMullen JA, Van Dyke TE, Horoszewicz HU, Genco RJ. Neutrophil chemotaxis in individuals with advanced periodontal disease and a genetic predisposition to diabetes mellitus. J Periodontol 1981; 52: 167-173.

17. Gwinn MR, Sharma A, De Nardin E. Single nucleotide polymorphisms of the N-formyl peptide receptor in localized juvenile periodontitis. J Periodontol 1999; 70: 1194-1201.

18. Seifert R, Wenzel-Seifert K. Defective $G_{I}$ protein coupling in 
two formyl peptide receptor mutants associated with localized juvenile periodontitis. J Biol Chem 2001; 276: 42043-42049.

19. Heinrich S, Pulverer G. Zur ätiologie und mikrobiologie des Actinomykose. III. Zentralblat Bakteriol Parasitenk Infectionskr Hyg Abt Orig 1959; 176: 91-101.

20. Slots J, Reynolds HS, Genco RJ. Actinobacillus actinomycetemcomitans in human periodontal disease: a cross-sectional microbiological investigation. Infect Immun 1980; 29: 10131020.

21. Frisken KW, Higgins T, Palmer JM. The incidence of periodontopathic micro-organisms in young children. Oral Microbiol Immunol 1990; 5: 43-45.

22. Kononen E, Asikainen S, Alaluusua S et al. Are certain oral pathogens part of the normal oral flora in denture-wearing edentulous subjects? Oral Microbiol Immunol 1991; 6: 119122 .

23. Sreenivasan PK, Meyer DH, Fives-Taylor PM. Factors influencing the growth and viability of Actinobacillus actinomycetemcomitans. Oral Microbiol Immunol 1993; 8: 361-369.

24. Kagermeier AS, London J. Actinobacillus actinomycetemcomitans strains Y4 and $\mathrm{N} 27$ adhere to hydroxyapatite by distinctive mechanisms. Infect Immun 1985; 47: 654-658.

25. Rosan B, Slots J, Lamont RJ, Listgarten MA, Nelson GM. Actinobacillus actinomycetemcomitans fimbriae. Oral Microbiol Immunol 1988; 3: 58-63.

26. Fine DH, Furgang D, Kaplan J, Charlesworth J, Figurski DH Tenacious adhesion of Actinobacillus actinomycetemcomitans strain CU1000 to salivary coated hydroxyapatite. Arch Oral Biol 1999; 44: 1063-1076.

27. Fine DH, Furgang D, Schreiner HC et al. Phenotypic variation in Actinobacillus actinomycetemcomitans during laboratory growth: implications for virulence. Microbiology 1999; 145 : 1335-1347.

28. Kachlany SC, Planet PJ, Bhattacharjee MK et al. Nonspecific adherence by Actinobacillus actinomycetemcomitans requires genes widespread in bacteria and archaea. J Bacteriol 2000; 182: 6169-6176.

29. Planet PJ, Kachlany SC, DeSalle R, Figurski DH. Phylogeny of genes for secretion NTPases: identification of the widespread tadA subfamily and development of a diagnostic key for gene classification. Proc Natl Acad Sci USA 2001; 98: 2503-2508.

30. Kachlany SC, Planet PJ, DeSalle R, Fine DH, Figurski DH, Kaplan JB. $f p-1$, the first representative of a new pilin gene subfamily, is required for non-specific adherence of Actinobacillus actinomycetemcomitans. Mol Microbiol 2001; 40: $542-$ 554

31. Kachlany SC, Planet PJ, DeSalle R, Fine DH, Figurski DH Genes for tight adherence of Actinobacillus actinomycetemcomitans: from plaque to plague to pond scum. Trends Microbiol 2001; 9: 429-437.

32. Mintz KP, Fives-Taylor PM. impA, a gene coding for an inner membrane protein. Influences colonial morphology of Actinobacillus actinomycetemcomitans. Infect Immun 2000; 68: 6580-6586

33. Mintz KP, Fives-Taylor PM. Binding of the periodontal pathogen Actinobacillus actinomycetemcomitans to extracellular matrix proteins. Oral Microbiol Immunol 1999; 14: 109-116.

34. Kaplan JB, Perry MB, MacLean LL, Furgang D, Wilson ME, Fine DH. Structural and genetic analysis of O-polysaccharide from Actinobacillus actinomycetemcomitans serotype f. Infect Immun 2001; 69: 5375-5384.

35. Kaplan JB, Schreiner HC, Furgang D, Fine DH. Population structure and genetic diversity of Actinobacillus actinomycetemcomitans strains isolated from localized juvenile periodontitis patients. J Clin Microbiol 2002; 40: 1181-1187.

36. Lally ET, Hill RB, Kieba IR, Korostoff J. The interaction between RTX toxins and target cells. Trends Microbiol 1999; 7: $356-361$.

37. Narayanan SV, Nagaraja TG, Chengappa MM, Stewart GC. Leukotoxins of gram-negative bacteria. Vet Microbiol 2002; 84 337-356.

38. Lally ET, Kieba IR, Sato A et al. RTX toxins recognize a $\beta_{2}$ integrin on the surface of human target cells. J Biol Chem 1997; 272: 30463-30469.

39. Lally ET, Golub EE, Kieba IR et al. Structure and function of the $\mathrm{B}$ and $\mathrm{D}$ genes of the Actinobacillus actinomycetemcomitans leukotoxin complex. Microb Pathog 1991; 11: 111-121.

40. Ohta H, Hara H, Fukui K, Kurihara H, Murayama Y, Kato K. Association of Actinobacillus actinomycetemcomitans leukotox- in with nucleic acids on the bacterial cell surface. Infect Immun 1993; 61: 4878-4884.

41. Berthold P, Forti D, Kieba IR, Rosenbloom J, Taichman NS, Lally ET. Electron immunocytochemical localization of Actinobacillus actinomycetemcomitans leukotoxin. Oral Microbiol Immunol 1992; 7: 24-27.

42. Kato S, Kowashi Y, Demuth DR. Outer membrane-like vesicles secreted by Actinobacillus actinomycetemcomitans are enriched in leukotoxin. Microb Pathog 2002; 32: 1-13.

43. Lally ET, Golub EE, Kieba IR et al. Analysis of the Actinobacillus actinomycetemcomitans leukotoxin gene: delineation of unique features and comparison to homologous toxins. J Biol Chem 1989; 264: 15451-15456.

44. Kachlany SC, Fine DH, Figurski DH. Secretion of RTX leukotoxin by Actinobacillus actinomycetemcomitans. Infect Immun 2000; 68: 6094-6100.

45. Korostoff J, Fei Wang J, Kieba I, Miller M, Shenker BJ, Lally ET. Actinobacillus actinomycetemcomitans leukotoxin induces apoptosis in HL-60 cells. Infect Immun 1998; 66: 4474-4483.

46. Korostoff J, Yamaguchi N, Miller M, Kieba I, Lally ET. Perturbation of mitochondrial structure and function plays a central role in Actinobacillus actinomycetemcomitans leukotoxin-induced apoptosis. Microb Pathog 2000; 29: 267-278.

47. Chen PB, Davern LB, Neiders ME, Reynolds HS, Zambon JJ. Analysis of in vitro lymphoproliferative responses and antibody formation following the subcutaneous injection of Actinobacillus actinomycetemcomitans and Wolinella recta in a murine model. Oral Microbiol Immunol 1991; 6: 12-16.

48. Kuritai Ochiai T, Ochiai K, Ikeda T. Immunosuppressive effects induced by Actinobacillus actinomycetemcomitans: effect on immunoglobulin production and lymphokine synthesis. Oral Microbiol Immunol 1992; 7: 338-343.

49. Kuritai-Ochiai T, Ochiai K. Immunosuppressive factor from Actinobacillus actinomycetemcomitans down regulates cytokine production. Infect Immun 1996; 64: 50-54.

50. Tagaya Y, Maeda Y, Mitsui A et al. ATL-driven factor (ADF), an IL-2receptor/Tac inducer homologous to thioredoxin: possible involvement of dithiol-reduction of the IL-2 receptor induction. $E M B O J 1989 ; 8$ : 757-764.

51. Henderson B, Tabona P, Poole S, Nair SP. Cloning and expression of the Actinobacillus actinomycetemcomitans thioredoxin (trx) gene and assessment of cytokine inhibitory activity. Infect Immun 2001; 69: 154-158.

52. Nalbant A, Zadeh HH. Evidence for apoptosis of the majority of $\mathrm{T}$ cells activated in vitro with Actinobacillus actinomycetemcomitans. Oral Microbiol Immunol 2000; 15: 290-298.

53. Zadeh HH, Nalbant A, Park K. Large-scale early in vitro response to Actinobacillus actinomycetemcomitans suggests superantigenic activation of T-cells. J Dent Res 2001; 80: $356-362$.

54. White PA, Wilson M, Nair SP, Kirby AC, Reddi K, Henderson B. Characterization of an antiproliferative surface-associated protein from Actinobacillus actinomycetemcomitans which can be neutralized by sera from a proportion of patients with localized juvenile periodontitis. Infect Immun 1995; 63: $2612-$ 2618.

55. White PA, Pater M, Nair S et al. Control of the human cell cycle by a bacterial protein, gapstatin. Eur J Cell Biol 1998; 77: $228-238$

56. Helgeland K, Nordby O. Cell cycle-specific growth inhibitory effect on human gingival fibroblasts of a toxin isolated from the culture medium of Actinobacillus actinomycetemcomitans. $J$ Periodont Res 1993; 28: 161-165.

57. Ohguchi M, Ishisaki A, Okahashi N et al. Actinobacillus actinomycetemcomitans toxin induces both cell cycle arrest in the $\mathrm{G}_{2} / \mathrm{M}$ phase and apoptosis. Infect Immun 1998; 66: 59805987.

58. Pickett CL, Whitehouse CA. The cytolethal distending toxin family. Trends Microbiol 1999; 7: 292-297.

59. De Rycke J, Oswald E. Minireview: Cytolethal distending toxin (CDT): a bacterial weapon to control host cell proliferation? FEMS Microbiol Lett 2001; 203: 141-148.

60. Lara-Tejero M, Galán JE. A bacterial toxin that controls cell cycle progression as a deoxyribonuclease I-like protein. Science 2000; 290: 354-357.

61. Sugai M, Kawamoto T, Peres SY et al. The cell cycle-specific growth-inhibitory factor produced by Actinobacillus actinomycetemcomitans is a cytolethal distending toxin. Infect Immun 1998; 66: 5008-5019. 
62. Mayer MPA, Bueno LAC, Hansen EJ, DiRienzo JM. Identification of a cytolethal distending toxin gene locus and features of a virulence-associated region in Actinobacillus actinomycetemcomitans. Infect Immun 1999; 67: 1227-1237.

63. Shenker BJ, McKay T, Datar S, Miller M, Chowhan R, Demuth D. Actinobacillus actinomycetemcomitans immunosuppressive protein is a member of the family of cytolethal distending toxins capable of causing a $\mathrm{G}_{2}$ arrest in human $\mathrm{T}$ cells. J Immunol 1999; 162: 4773-4780.

64. Shenker BJ, Hoffmaster RH, McKay TL, Demuth DR. Expression of the cytolethal distending toxin $(c d t)$ operon in Actinobacillus actinomycetemcomitans: evidence that the CdtB protein is responsible for $\mathrm{G}_{2}$ arrest of the cell cycle in human T cells. J Immunol 2000; 165: 2612-2618.

65. Shenker BJ, Hoffmaster RH, Zekavat A, Lally NET, Demuth $\mathrm{DR}$, Yamaguchi N. Induction of apoptosis in human T cells by Actinobacillus actinomycetemcomitans cytolethal distending toxin is a consequence of G2 arrest of the cell cycle. $J$ Immunol 2001; 167: 435-441.

66. Akifusa S, Poole S, Lewthwaite J, Henderson B, Nair SP Recombinant Actinobacillus actinomycetemcomitans cytolethal distending toxin proteins are required to interact to inhibit human cell cycle progression and to stimulate human cytokine synthesis. Infect Immun 2001; 69: 5925-5930.

67. Akifusa S, Nair SP, Sharp LJ, Stenbeck G, Henderson B. Mechanism of internalization of the cytolethal distending toxin of Actinobacillus actinomycetemcomitans. Infect Immun (in press).

68. Young RS, Fortney KR, Gelfanova V et al. Expression of cytolethal distending toxin and hemolysin is not required for pustule formation by Haemophilus ducreyi in human volunteers. Infect Immun 2001; 69: 1938-1942.

69. Tolo K, Helgeland K. Fc binding components: a virulence factor in Actinobacillus actinomycetemcomitans? Oral Microbiol Immunol 1991; 6: 373-377.

70. Mintz KP, Fives-Taylor PM. Identification of an immunoglobulin Fc receptor of Actinobacillus actinomycetemcomitans. Infect Immun 1994; 62: 4500-4505.

71. White PA, Nair SP, Kim M-J, Wilson M, Henderson B. Molecular characterization of an outer membrane protein of Actinobacillus actinomycetemcomitans belonging to the OmpA family. Infect Immun 1998; 66: 369-372.

72. Weiser JN, Gotschlich EC. Outer membrane protein A (OmpA) contributes to serum resistance and pathogenicity of Escherichia coli K-1. Infect Immun 1991; 59: 2252-2258.

73. Kato T, Okudo K. Actinobacillus actinomycetemcomitans possesses an antigen binding to anti-human IL-10 antibody. FEMS Microbiol Lett 2001; 204: 293-297.

74. Van Dyke TE, Bartholomew E, Genco RJ, Slots J, Levine MJ. Inhibition of neutrophil chemotaxis by soluble bacterial products. $J$ Periodontol 1992; 53: 502-508.

75. Huang GT-J, Kim D, Lee JK-H, Kuramitsu HK, Haake SK. Interleukin-8 and intercellular adhesion molecule 1 regulation in oral epithelial cells by selected periodontal bacteria: multiple effects of Porphyromonas gingivalis via antagonistic mechanisms. Infect Immun 2001; 69: 1364-1372.

76. Uchida Y, Shiba H, Komatsuzawa $\mathrm{H}$ et al. Expression of IL-1 $\beta$ and IL-8 by human gingival cells in response to Actinobacillus actinomycetemcomitans. Cytokine 2001; 14: 152-161.

77. Reddi K, Nair SP, White PA et al. Surface-associated material from the bacterium Actinobacillus actinomycetemcomitans contains a peptide which, in contrast to lipopolysaccharide, directly stimulates fibroblast interleukin-6 gene transcription. Eur J Biochem 1996; 236: 871-876.

78. Tani Y, Tani M, Kato I. Extracellular 37-kDa antigenic protein from Actinobacillus actinomycetemcomitans induces TNF $\alpha$, IL$1 \beta$, and IL-6 in murine macrophages. $J$ Dent Res 1997; 76: $1539-1547$.

79. Nishihara T, Koga T, Hamada S. Extracellular proteinaceous substances from Haemophilus actinomycetemcomitans induce mitogenic responses in murine lymphocytes. Oral Microbiol Immunol 1987; 2: 48-52.

80. Jeong S-J, Yee S-T, Jo W-S et al. A novel factor isolated from Actinobacillus actinomycetemcomitans stimulates mouse B cells and human peripheral blood mononuclear cells. Infect Immun 2000; 68: 5132-5138.

81. Nakano Y, Suzuki N, Yoshida Y, Nezu T, Yamashita Y, Koga T. Thymidine diphosphate-6-deoxy-L-lyxo-4-hexulose reductase synthesising dTDT-6-deoxy-L-talose from Actinobacillus acti- nomycetemcomitans. J Biol Chem 2000; 275: 6806-6812.

82. Suzuki N, Nakano Y, Yoshida Y, Nakao H, Yamashita Y, Koga T. Genetic analysis of the gene cluster for the synthesis of serotype a-specific polysaccharide antigen in Actinobacillus actinomycetemcomitans. Biochim Biophys Acta 2000; 1517: $135-138$.

83. Arnett TR, Henderson B (eds). Methods in bone biology. London, Chapman \& Hall. 1998.

84. Horowitz MC, Ki Y, Wilson M, Kacena MA. Control of osteoclastogenesis and bone resorption by members of the TNF family of receptors and ligands. Cytokine Growth Factor Rev 2001; 12: 9-18.

85. Yoshimura A, Kaneko T, Kato Y, Golenbock DT, Hara Y. Lipopolysaccharides from periodontopathic bacteria Porphyromonas gingivalis and Capnocytophaga ochracea are antagonists for human toll-like receptor 4. Infect Immun 2002; 70: $218-225$.

86. Ino Y, Hopps RM. The bone-resorbing activities in tissue culture of lipopolysaccharides from the bacteria Actinobacillus actinomycetemcomitans, Bacteroides gingivalis and Capnocytophaga ochracea isolated from human mouths. Arch Oral Biol 1984; 29: 59-63.

87. Ishihara Y, Nishihara T, Maki E, Noguchi T, Koga T. Role of interleukin-1 and prostaglandin in in vitro bone resorption induced by Actinobacillus actinomycetemcomitans lipopolysaccharide. J Periodont Res 1991; 26: 155-160.

88. Nishida E, Hara Y, Kaneko T, Ikeda Y, Ukai T, Kato I. Bone resorption and local interleukin-1 alpha and interleukin-1 beta synthesis induced by Actinobacillus actinomycetemcomitans and Porphyromonas gingivalis lipopolysaccharide. J Periodont Res 2001; 36: 1-8.

89. Reddi K, Wilson M, Poole S, Meghji S, Henderson B. Relative cytokine-stimulating activities of surface components of the oral periodontopathic bacterium Actinobacillus actinomycetemcomitans. Cytokine 1995; 7: 534-541.

90. Kirby AC, Meghji S, Nair SP et al. The potent bone-resorbing mediator of Actinobacillus actinomycetemcomitans is homologous to the molecular chaperone GroEL. J Clin Invest 1995; 96: $1185-1194$

91. Goulhen F, Hafezi A, Uitto V-J et al. Subcellular localization and cytotoxic activity of the GroEL-like protein isolated from Actinobacillus actinomycetemcomitans. Infect Immun 1998; 66: $5307-5313$

92. Reddi K, Meghji S, Nair SP et al. The Escherichia coli chaperonin 60 (groEL) is a potent stimulator of osteoclast formation. J Bone Miner Res 1998; 13: 1260-1266.

93. Nishihara T, Ueda N, Anano $\mathrm{K}$ et al. Actinobacillus actinomycetemcomitans Y4 capsular-polysaccharide-like polysaccharide promotes osteoclast-like cell formation by interleukin-1 $\alpha$ production in mouse marrow cultures. Infect Immun 1995; 63: 1893-1898

94. Yamamoto S, Mogi M, Kinpara K et al. Anti-proliferative capsular-like polysaccharide antigen from Actinobacillus actinomycetemcomitans induces apoptotic cell death in mouse osteoblastic MC3T3-E1 cells. J Dent Res 1999; 78: 12301237.

95. Kawai T, Eisen-Lev R, Seki M, Eastcott JW, Wilson ME, Taubman MA. Requirement of B7 costimulation for Th1mediated inflammatory bone destruction in experimental periodontal disease. J Immunol 2000; 164: 2102-2109.

96. Teng Y-T, Nguyen $\mathrm{H}$, Gao X et al. Functional human T-cell immunity and osteoprotegerin ligand control alveolar bone destruction in periodontal infection. J Clin Invest 2000; 106: R59-R67.

97. Wilson M, McNab R, Henderson B. Bacterial disease mechanisms: an introduction to cellular microbiology. Cambridge, Cambridge University Press. 2002.

98. Holt SC, Tanner AC, Socransky SS. Morphology and ultrastructure of oral strains of Actinobacillus actinomycetemcomitans and Haemophilis aphrophilus. Infect Immun 1980; 30: $588-600$.

99. Inouye T, Ohta H, Kokeguchi S, Fukui K, Kato K. Colonial variation and fimbriation of Actinobacillus actinomycetemcomitans. FEMS Microbiol Lett 1990; 57: 13-17.

100. Inoue T, Tanimoto I, Ohta H, Kato K, Murayama Y, Fukui K Molecular characterization of low-molecular-weight component protein, Flp, in Actinobacillus actinomycetemcomitans fimbriae. Microbiol Immunol 1998; 42: 253-258

101. Inoue $\mathrm{T}$, Ohta $\mathrm{H}$, Tanimoto $\mathrm{I}$, Shingaki R, Fukui $\mathrm{K}$. 
Heterogeneous post-translational modification of Actinobacillus actinomycetemcomitans fimbrillin. Microbiol Immunol 2000; 44: $715-718$.

102. Haase EM, Zmuda JL, Scannapieco FA. Identification and molecular analysis of rough-colony-specific outer membrane proteins of Actinobacillus actinomycetemcomitans. Infect Immun 1999; 67: 2901-2908.

103. Fuller TE, Kennedy MJ, Lowery DE. Identification of Pasteurella multocida virulence genes in a septicemic mouse model using signature-tagged mutagenesis. Microb Pathog 2000; 29: 25-38.

104. Oelschlaeger TA, Hacker J. Bacterial invasion into eukaryotic cells. New York, Kluwer Academic. 2000.

105. Meyer DH, Sreenivasan PK, Fives-Taylor PM. Evidence for invasion of a human oral cell line by Actinobacillus actinomycetemcomitans. Infect Immun 1991; 59: 2719-2726.

106. Lepine G, Caudry S, DiRienzo JM, Ellen RP. Epithelial cell invasion by Actinobacillus actinomycetemcomitans strains from restriction fragment length polymorphism groups associated with juvenile periodontitis or carrier status. Oral Microbiol Immunol 1998; 13: 341-347.

107. Meyer DH, Mintz KP, Fives-Taylor PM. Models of invasion of enteric and periodontal pathogens into epithelial cells: a comparative analysis. Crit Rev Oral Biol Med 1997; 8: 389409.

108. Schenkein HA, Barbour SE, Berry CR, Kipps B, Tew JG. Invasion of human vascular endothelial cells by Actinobacillus actinomycetemcomitans via the receptor for platelet-activating factor. Infect Immun 2000; 68: 5416-5419.

109. Swords WE, Buscher BA, Ver Steeg K et al. Non-typeable Haemophilis influenzae adhere to and invade human bronchial epithelial cells via an interaction of lipooligosaccharide with the PAF receptor. Mol Microbiol 2000; 37: 13-27.

110. Sreenivasan PK, Meyer DH, Fives-Taylor PM. Requirement for invasion of epithelial cells by Actinobacillus actinomycetemcomitans. Infect Immun 1993; 61: 1239-1245.

111. Meyer DH, Lippman JE, Fives-Taylor PM. Invasion of epithelial cells by Actinobacillus actinomycetemcomitans: a dynamic multistep process. Infect Immun 1996; 64: 29882997.

112. Meyer DH, Rose JE, Lippman JE, Fives-Taylor PM. Microtubules are associated with intracellular movement and spread of the periodontopathogen Actinobacillus actinomycetemcomitans. Infect Immun 1999; 67: 6518-6525.

113. Rudney JD, Chen R, Sedgewick GJ. Intracellular Actinobacillus actinomycetemcomitans and Porphyromonas gingivalis in buccal epithelial cells collected from human subjects. Infect Immun 2001; 69: 2700-2707.

114. Fong KP, Chung WO, Lamont RJ, Demuth DR. Intra- and interspecies regulation of gene expression by Actinobacillus actinomycetemcomitans LuxS. Infect Immun 2001; 69: 76257634.

115. Viallard J-F, Bonnet S, Couzi L et al. Glomerulonephritis caused by Actinobacillus actinomycetemcomitans mimicking c-ANCA-positive vasculitis. Nephrol Dial Transplant 2002; 17: $663-665$. 